Article

\title{
Subterranean Invasion by Gapped Ringed Crayfish: Effectiveness of a Removal Effort and Barrier Installation
}

\author{
Joshua Mouser ${ }^{1}{ }^{\mathbb{C}}$, David C. Ashley ${ }^{2}$, Tom Aley ${ }^{3}$ and Shannon K. Brewer ${ }^{4, *}$ \\ 1 Oklahoma Cooperative Fish and Wildlife Research Unit, Oklahoma State University, Stillwater, OK 74078, \\ USA; jbmouse@okstate.edu \\ 2 Department of Biological Sciences, Missouri Western State University, Saint Joseph, MO 64507, USA; \\ ashley@missouriwestern.edu \\ 3 Ozark Underground Laboratory, Protem, MO 65733, USA; taley@ozarkundergroundlab.com \\ 4 U.S. Geological Survey, Oklahoma Cooperative Fish and Wildlife Research Unit, Oklahoma State University, \\ Stillwater, OK 74078, USA \\ * Correspondence: shannon.brewer@okstate.edu; Tel.: +1-405-744-9841
}

Received: 31 October 2018; Accepted: 25 December 2018; Published: 29 December 2018

\begin{abstract}
Non-native crayfish invasion is a major threat to many stream fauna; however, invasions in subterranean habitats are rarely documented. Our study objectives were to examine demographics and morphological and life-history traits of a gapped ringed crayfish Faxonius neglectus chaenodactylus population that invaded Tumbling Creek Cave and determine the effects of removal on the population. Crayfish were found throughout the cave though fewer individuals were observed upstream of an installed weir. Fecund females were collected in nearly all months, but were prevalent during spring (February-June). Males and females were of similar sizes. Males had larger chelae and chelae that were regenerated slightly more often than females. Removal of $>4000$ crayfish since 2011 resulted in reduced abundances, but the population persisted. Age estimates from counting bands on gastric mills indicated crayfish within the cave lived longer than populations in nearby Big Creek (6 vs. 4 years). Recent efforts to prevent upstream cave migrations included a barrier installation and since installation, few crayfish have been located upstream. We show that exploitation of new environments may lead to trait changes (i.e., reproduction and longevity). We also demonstrate that barriers reduce the spread of invasion at a comparable cost to removal. We hypothesize that increased reservoir elevation inundates springs hydrologically connected to the cave and this may be the invasion source.
\end{abstract}

Keywords: invasive crayfish; Faxonius neglectus chaenodactylus; stygobionts; karst; cave

\section{Introduction}

The introduction of nonindigenous species is considered one of the greatest threats to aquatic ecosystems [1,2] and crayfishes are among the most harmful invasive aquatic species [3]. Crayfishes are keystone species [4]; therefore, invasive crayfishes can have drastic effects on the native community. For example, invasive crayfishes can result in the reduction of macrophytes [5], macroinvertebrates [6], fishes [7], amphibians [8], and native crayfishes [9]. The effects of invasive crayfishes on surface waters have been well documented, but invasions in subterranean streams are less common or undocumented (but see [10]).

Subterranean invasions are of particular concern due to the delicate nature of karst ecosystems, and the role of stygobionts as indicators of good water quality. Stygobionts (i.e., organisms adapted for life in groundwater) have a high risk of extinction because they are often narrow-range endemics [11], slow growing, long lived, and have few young, [12]. The presence of stygobionts is often indicative 
of good groundwater quality [13]; therefore, they are beneficial to humans as biomonitoring targets. Many societies rely on groundwater because it comprises $95 \%$ of the world's available freshwater [14]. Additionally, groundwater benefits economies because it is used as the primary source of irrigation water where $40 \%$ of the world's food is grown [14].

The ringed crayfish Faxonius neglectus is a problematic invader across the United States, a common inhabitant of caves, and a potential threat to groundwater ecosystems. Areas invaded by ringed crayfish include New York [15], Oregon [16], and catchments in Missouri that are outside of its native range [17]. The ringed crayfish has been reported in at least 71 caves in Arkansas and Missouri and it is considered a stygophile [18], or styoxene [19]. Styogophiles are aquatic organisms that can complete their life cycles either inside or outside caves, whereas stygoxenes must obtain some of their living requirements from the surface [20]. In some cases, the term invasive species may be appropriate for ringed crayfish occupying caves because their movement into caves can be linked to anthropogenic activities and they may harm native cave species. For example, the ringed crayfish is considered an invasive species within Tumbling Creek Cave in Missouri, USA, because increased reservoir elevation is thought to have facilitated movement into the cave, which threatens the native community.

The ringed crayfish is a potential threat to the native species of Tumbling Creek Cave and, therefore, has been the subject of targeted removal from Tumbling Creek Cave since 2011. The non-native crayfish is considered especially problematic for the federally endangered Tumbling Creek cavesnail Antrobia culveri, which could be a potential food source for crayfish. Studies have shown that intensive trapping of invasive crayfish can reduce the population and increase native organisms such as fish and macrophytes [21]. We hypothesize that the removal of the ringed crayfish will reduce the population abundance thereby helping to protect the native species of Tumbling Creek Cave. Our study objectives were to examine population demographics of a ringed crayfish population occupying a cave, and determine the effects of systematic removal on the crayfish over a 7-yr period. We provide demographic and trait data (i.e., reproductive timing and longevity) on populations occupying the cave because these data are useful for developing population models and making predictions about removal success or invasion potential. This study provides a useful assessment of different removal approaches and the cost and effort required. Case studies such as this are needed to improve our efforts of removing non-native and invasive species.

\section{Materials and Methods}

\subsection{Study Area}

Tumbling Creek Cave is located in the biologically-diverse Ozark Highlands of southern Missouri, USA (Figure 1). The Ozark Highland ecoregion is relatively humid (annual rainfall: 104-125 cm) and typified by rugged hills, clear-flowing streams, and karst topography [22]. The recharge area of Tumbling Creek Cave is 2,336 ha, with $75 \%$ of that area under private land ownership. Tumbling Creek exits the cave as an intermittent stream and the channel meets the confluence with Big Creek about 1200-m downstream. The cave entrance is gated and an exclusion screen (i.e., metal flashing) approximately $30-\mathrm{cm}$ tall is attached to the base. The exclusion screen was erected to keep crayfishes and fishes from entering the cave when the stream has water, but was never evaluated because that section of stream is often dry. The water levels and flow patterns of Tumbling and Big creeks are affected by water levels of a downstream reservoir. 


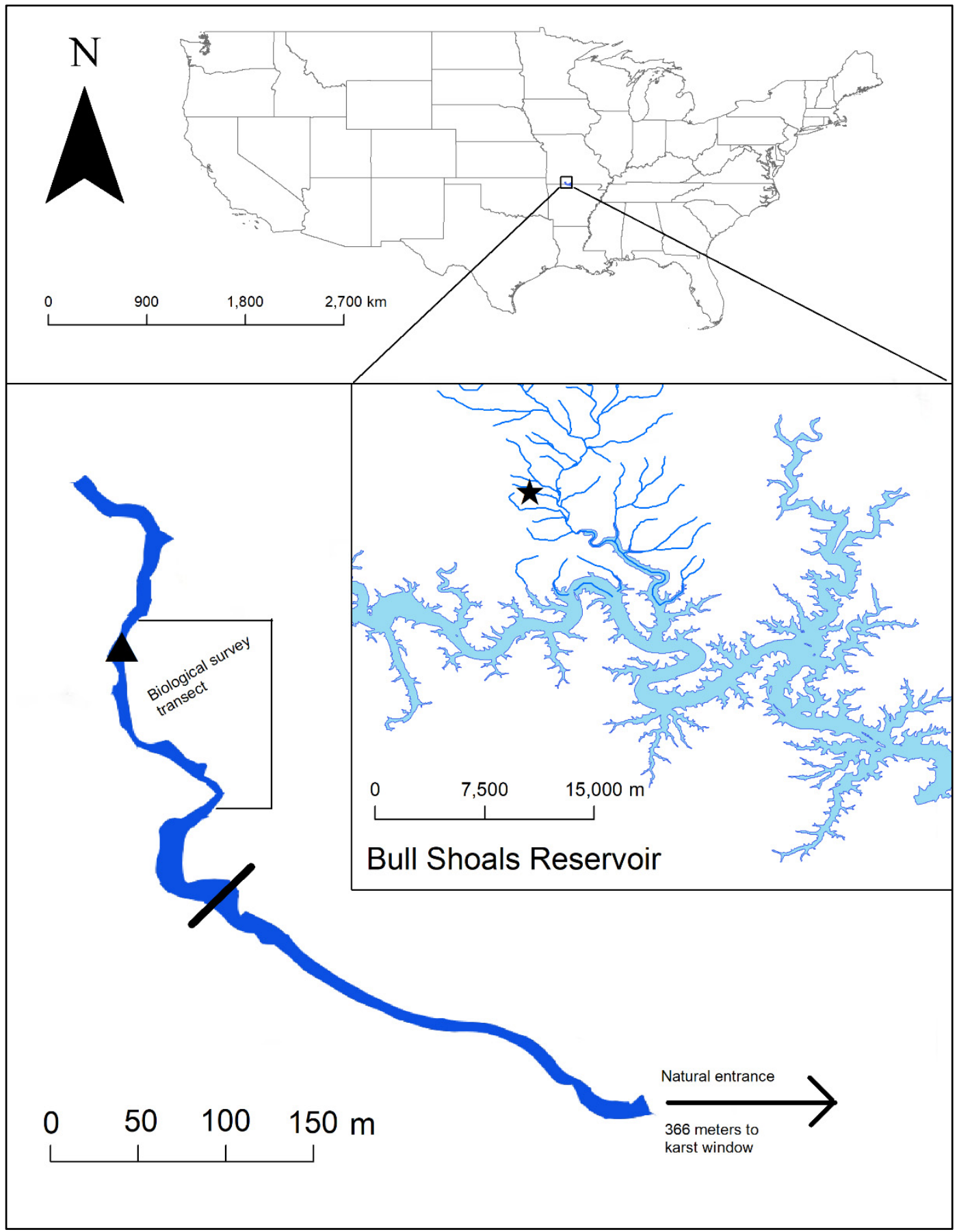

Figure 1. Location of Tumbling Creek Cave in Missouri, USA. The star represents the location of Tumbling Creek Cave at the headwaters of Tumbling Creek of the Ozark Highlands ecoregion. A crayfish barrier (solid black line) was installed in 2018 and a weir (triangle) was installed in 1968.

The elevation of the downstream reservoir inundates springs and nearby creeks that are hydrologically connected to Tumbling Creek Cave. The cave entrance is approximately 3500-m upstream of Bull Shoals Reservoir (Figure 1), but only approximately $400 \mathrm{~m}$ when the flood pool of the reservoir is maximized at approximately $212 \mathrm{~m}$. The reservoir inundates several of the springs that drain to the cave at approximately 200-m in elevation (Figure 2). The elevation of the lowest spring (unnamed) draining Tumbling Creek Cave is $204.5 \mathrm{~m}$ and the highest spring (perennial, Powerline Spring) is $207.5 \mathrm{~m}$. Powerline Spring is situated on Big Creek and groundwater traces indicate that this spring drains Tumbling Creek Cave (Aley, unpublished data). There is a karst window located 
about $366 \mathrm{~m}$ from the cave entrance (Figure 1). The karst window is approximately $520 \mathrm{~m}$ to the lowest unnamed spring and $457 \mathrm{~m}$ to Powerline Spring.

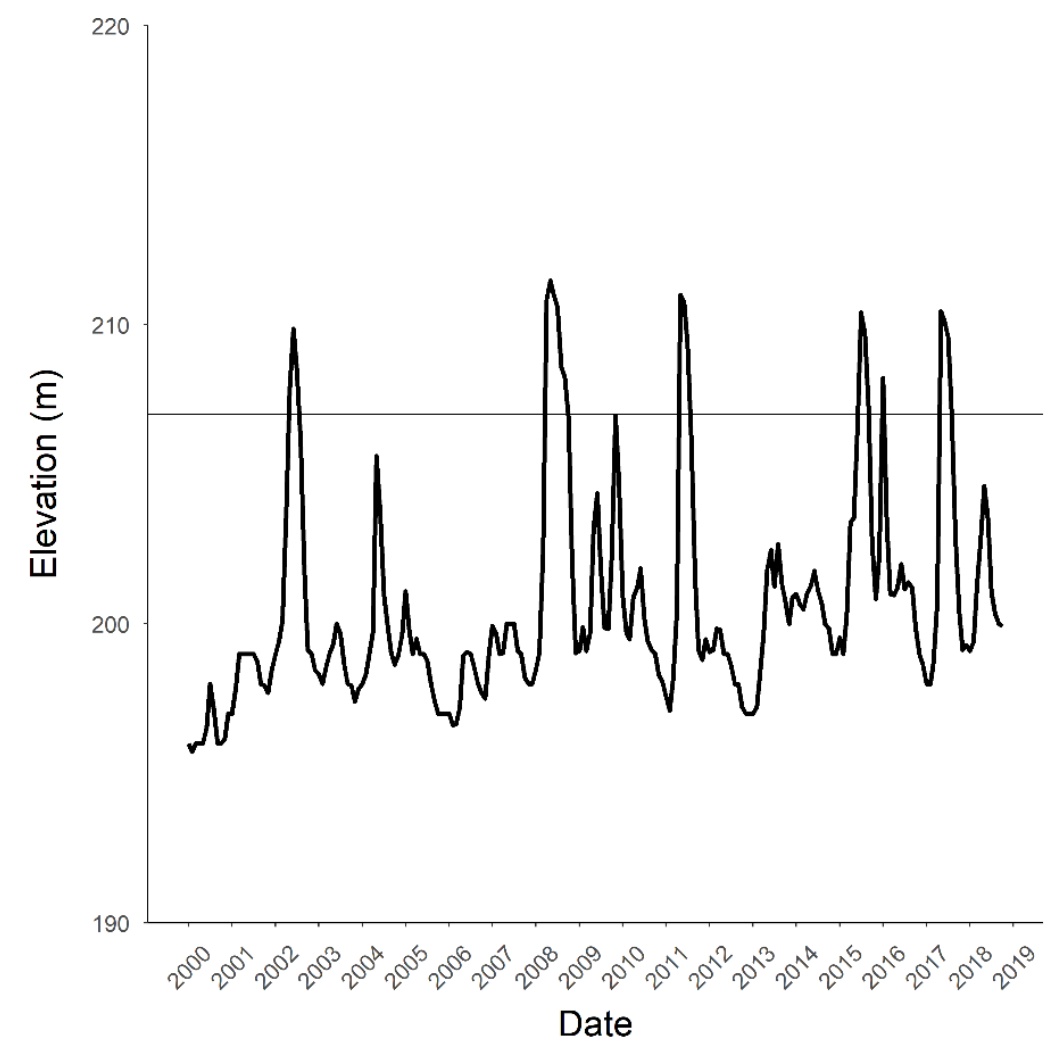

Figure 2. Elevation of Bull Shoals Reservoir from January 2000-October 2018 (coinciding with our biological surveys). One invasion hypothesis is that the reservoir elevation facilitates movement of gapped ringed crayfish Faxonius neglectus chaenodactylus into Tumbling Creek Cave. Several of the springs that drain to the cave are inundated when the reservoir elevation reaches 204-207 m (shown by line).

Tumbling Creek Cave contains 118 species, including several stygobionts found within Tumbling Creek and the ringed crayfish Faxonius neglectus neglectus ([19]; Aley, unpublished data). More recent molecular work determined the ringed crayfish located in the Tumbling Creek catchment was previously misidentified and is actually the gapped ringed crayfish Faxonius neglectus chaenodactylus [23]. The gapped ringed crayfish is native to the surface streams of the catchment, but is non-native to karst environments. However, the federally-endangered Tumbling Creek cavesnail is endemic to the cave [24]. In addition, several other native members of the aquatic community are considered species of conservation concern including an isopod Caecidotea antricola, two species of amphipods, Stygobromus onondagaensis and S. ozarkensis [25] and the larval stages of an Ozark endemic salamander Eurycea nerea [26]. The authors have also noted possible sightings of stygobiotic crayfish throughout the years, but have never captured a specimen for identification. Six stygobiotic crayfish species, however, have been verified through collections in other cave systems located within $100 \mathrm{~km}$ of Tumbling Creek Cave.

\subsection{Crayfish Surveys and Morphometric Traits}

Initial catch-and-release crayfish trapping in Tumbling Creek Cave began in March 2001. Our trapping efforts were conducted with the goal of acquiring a specimen to determine the identity of the cave-adapted species previously observed in the cave. Before our initial efforts, we noticed 
occasional epigean crayfish in the cave stream, but did not know how abundant they were in the cave system.

We set traps in the cave stream (Tumbling Creek) where we were conducting an extensive biological survey. This area was located in the cave approximately $457 \mathrm{~m}$ from the natural entrance (Figure 1). The study area was approximately 82-m long. Upstream of the study area, the stream extended for approximately $91 \mathrm{~m}$ to a very low crawl area that was too difficult to negotiate for biological sampling. Originally (16 March 2001), we set ten traps approximately 5-20 m apart at each sampling event (see below), but beginning in 2011 (19 February 2011), we added five additional traps on each subsequent survey trip. The additional traps were placed upstream of the original sample area with the most upstream trap near the very low crawl space described above (i.e., the additional traps were similarly spaced in proximity of one another compared to the original 10 traps). The traps were set at approximately the same location (e.g., same pool) on each sample trip.

We deployed our crayfish traps (modified IPC YellowJacket Traps, Sterling International, Spokane) at night and retrieved them the following morning. Our traps were plastic cylinders $(22-\mathrm{cm}$ long by 8 -cm diameter). A string attached to a perforated plastic lid was used to anchor the upstream end of the trap in the streambed. The downstream end of the trap consisted of a perforated funnel which projected into the trap. The point of this funnel was trimmed to a 3-cm diameter (i.e., large enough to allow a crayfish to enter). The funnel was secured in the trap by screwing a lid (Mason jar) on the downstream end of the trap. We baited our traps with a piece of raw chicken wing. Traps would typically be in the cave 10-15 $\mathrm{h}$ before they were examined for crayfish. Occasionally, the presence of federally-endangered gray bats Myotis grisescens would prevent us from entering the area where the last five traps were intended to be set.

As we conducted the stream biota survey, we collected the traps, and processed and released or retained the specimens. Any crayfish trapped were placed into a separate container for processing. Specimens were processed by recording gender, female reproductive state (non-reproductive females or females carrying embryos), measured $(1.0 \mathrm{~mm})$ for a variety of morphometric traits (total length [TL], carapace length [CL], head length, body width, left chela length, right chela length), and weighed (0.1 g). Prior to 22 June 2011, crayfish captured were released near the location where they were trapped post processing. After we initiated a removal plan (22 June 2011), trapped crayfish were always removed from the cave and euthanized via freezing.

\subsection{Crayfish Removal}

Crayfish removal began June 2011 with the goal of reducing the number of gapped ringed crayfish found in Tumbling Creek Cave. Initial trapping efforts were limited due to available funding, but increased over time. Traps were similar to those used for the biological surveys and left in the stream permanently. If possible, the traps were emptied once a week and rebaited with hotdogs. In 2011 and most of 2012, only the lower biological survey area was trapped (number of traps $\approx 10$ ). At the end of 2012 , the trapping area was expanded to include the upper portion of the biological survey area and the area down to where the dam would eventually be constructed (number of traps $\approx 25$ ). During that time, many lower reaches (i.e., near the exclusion barrier, Figure 1) were not trapped from late March through early November due to the presence of clusters of gray bats. After 2014, trapping was conducted throughout the year with the exception of when the bats were birthing ( $\approx$ mid-May through mid-June). Trapping effort was increased at the end of 2014 ( $\mathrm{N} \approx 35$ traps), partway through 2015 $(\mathrm{N} \approx 45)$, and again at the end of $2017(\mathrm{~N} \approx 55)$. Crayfish $(\mathrm{N}=22)$ were retained from the removal event on 5 September 2018 to age via the gastric mill.

\subsection{Statistical Analysis}

We used $t$-tests and linear regression relationships $(\alpha \leq 0.05)$ to examine variation in population demographics between male and female crayfish and population trends. We compared the difference between $C L$, weight, and chelae size between male and female crayfish using $t$-tests. We met the 
assumptions of linearity, homogeneity of variances, and normality. Until 25 October 2005, CL was not recorded, so we developed a linear regression equation between TL and CL to estimate CL for earlier years (due to CL most often being reported for crayfishes). Additionally, we developed a simple linear regression relationship between the size of the left and right chelae to determine level of aggression between the sexes. Because crayfish use chelae for defense against predators and in social interactions among individuals (see [27] for an overview), a size comparison between chelae should reflect aggressive behavior. Both male and female crayfish are known to display fighting behaviors, particularly during reproductive periods [27]. We have no information to suggest that either males or females would show more aggressive behavior in karst systems. Finally, we averaged the annual crayfish catch per trap from both biological surveys and removal efforts and developed a simple regression between average crayfish per trap over time. All analyses were conducted using SPSS (IBM-SPSS Statistics Version 23).

\subsection{Age Comparison of Surface and Subterranean Populations}

We conducted surveys of epigean crayfish in the same catchment as Tumbling Creek to provide an age comparison to the subterranean population. We sampled crayfish over a 2-day period during September 2018. Sampling was completed using seining, and visual search and capture by hand. Using a combination of techniques is required to meet the assumptions associated with length-frequency histograms [28]. The seine was quickly pulled downstream for approximately 10 meters or held at the base of riffles while a third person dislodged the upstream substrate. We also spent time at each stream searching a variety of wadeable habitats and capturing all located crayfish by hand or using nets. Rocks and other cover were gently moved during our searches to capture crayfish of a variety of sizes. All crayfish captured were measured $(\mathrm{CL}, 1.0 \mathrm{~mm})$ and most were returned to the stream. A subset of 45 crayfish that were representative of the sizes captured (20 crayfish: $11-20 \mathrm{~mm}$, 20 crayfish: $21-30 \mathrm{~mm}$, and 5 crayfish: $31+\mathrm{mm}$ ) was retained to age via the gastric mill.

We estimated epigean crayfish age using both length-frequency histograms and the gastric mill. Length-frequency histograms are useful for aging young crayfish [29], but using the gastric mill to age larger individuals is more informative about longevity [30]. We developed length-frequency histograms using CL data from all of the sampled crayfish. We used the Bhattacharya method to identify age classes from the length-frequency histograms [31] using the R package TropFishR [32]. The Bhattacharya method is a modal progression analysis that infers growth from the shift of modes in length-frequency histograms [33]. Crayfish gastric mills were processed and aged following the methods of [30]. Briefly, gastric mills were extracted from the crayfish, the tissue was removed using forceps, the zygocardiac ossicles were mounted individually in epoxy resin, and then sectioned. We retained the clearest section from each of the zygocardiac ossicles, which were all mounted on one slide. Each slide was aged independently by two different readers and if ages were not in agreement, we came to a consensus age. Age estimates via the length-frequency histogram were compared to age estimates obtained via the gastric mill.

\subsection{Barrier Installations}

Both a v-notch weir and a crayfish barrier (i.e., a dam that allowed some water to pass through) were constructed in the cave portion of Tumbling Creek. A v-notch weir was installed within the cave in 1968 (Figure 1). The purpose of the weir was to measure streamflow rather than prevent crayfish or other organisms from moving throughout the stream. The barrier was installed in spring 2018 (i.e., after funding was acquired and the project was approved) specifically for the purpose of deterring or preventing upstream migration by crayfish. Total height of the barrier was $29 \mathrm{~cm}$ and the top $9.5 \mathrm{~cm}$ of this wall overhung the bottom portion on the downstream side by $2.5 \mathrm{~cm}$ (Figure 3). 


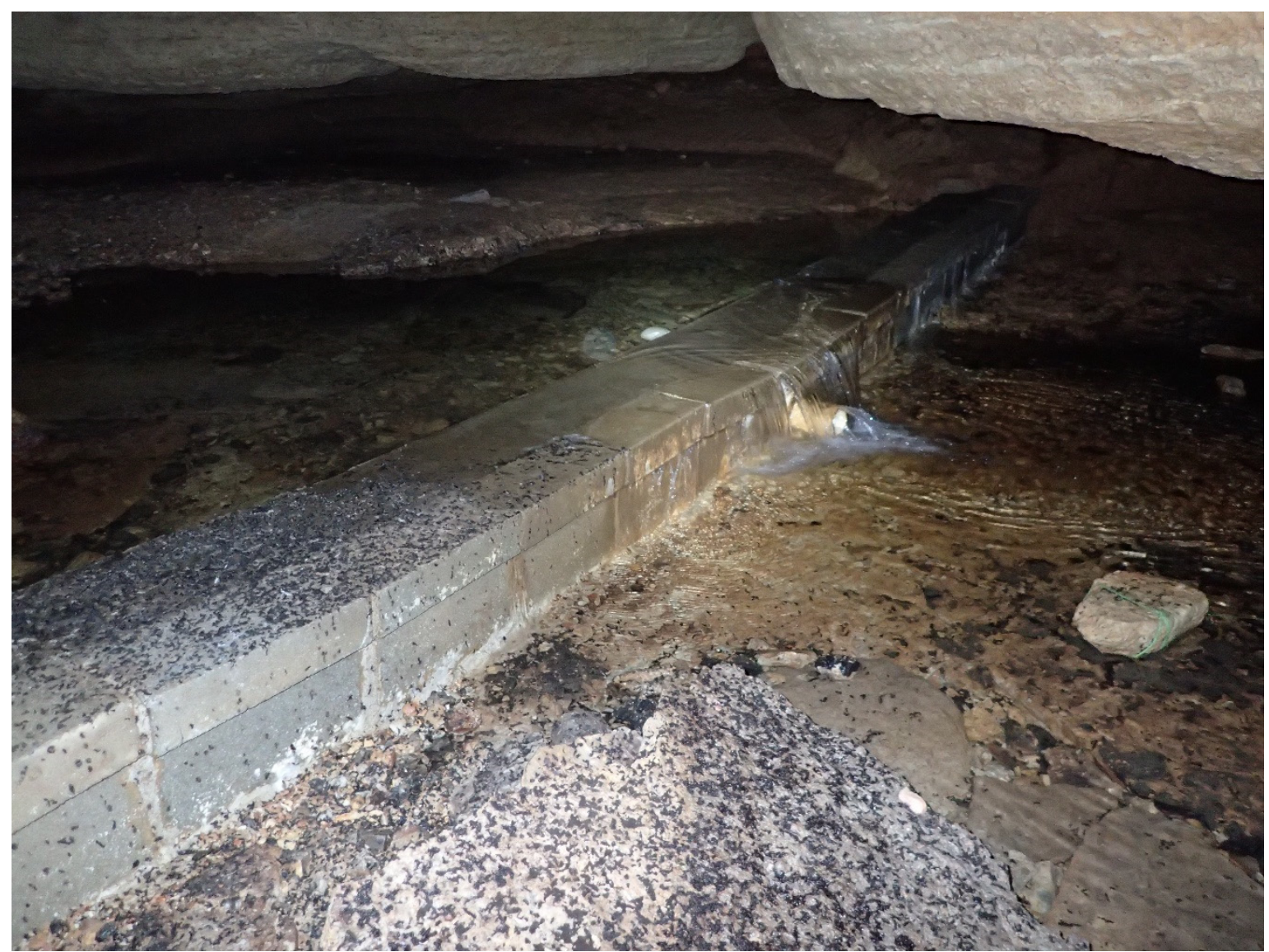

Figure 3. Barrier installed in Tumbling Creek to stop movement of gapped ringed crayfish Faxonius neglectus chaenodactylus to upstream reaches of the cave. Total height of the barrier is $29 \mathrm{~cm}$ and the top $9.5 \mathrm{~cm}$ of this wall overhangs the bottom portion on the downstream side by $2.5 \mathrm{~cm}$. Since the barrier was completed, only a few crayfish have been found and removed from above the barrier (not as part of a biological survey

\section{Results}

\subsection{Crayfish Surveys and Morphometric Traits}

The biological surveys provide the first detailed morphometrics for epigean crayfish in caves. We captured and examined morphological traits on 646 gapped ringed crayfish resulting from 39 trapping events from March 2001 to September 2018. No other crayfish species were captured. We captured a broad range of crayfish sizes from within the cave (Figure 4). Captured females and males were of similar CL (female mean $C L=28.8 \pm 5.6 \mathrm{~mm}, \mathrm{~N}=366$; male mean $\mathrm{CL}=28.1 \pm 5.0 \mathrm{~mm}$, $\mathrm{N}=243 ; \mathrm{t}=1.646, \mathrm{df}=607, P=0.09$ ) and weights were also not significantly different (male mean mass $=7.6 \pm 3.9 \mathrm{~g}, \mathrm{~N}=213$; female mean mass $=7.6 \pm 3.8 \mathrm{~g}, \mathrm{~N}=320 ; \mathrm{t}=-0.211, \mathrm{df}=531, P=0.83$ ). Captured males had significantly larger chelae (mean chelae length $=20.7 \pm 7.1 \mathrm{~mm}$ ) than females (mean chelae length $17.1 \mathrm{~mm} \pm 5.2 ; \mathrm{t}=-6.366, \mathrm{df}=343.9, P<0.001$ ). Linear relationships between the left versus right chela lengths of male $\left(Y=0.89 X+2.23 ; R^{2}=0.69\right)$ and female crayfish $\left(Y=0.92 X+1.18 ; R^{2}=0.81\right)$ suggest males regenerate their chelae slightly more often than females (Figure 5). 

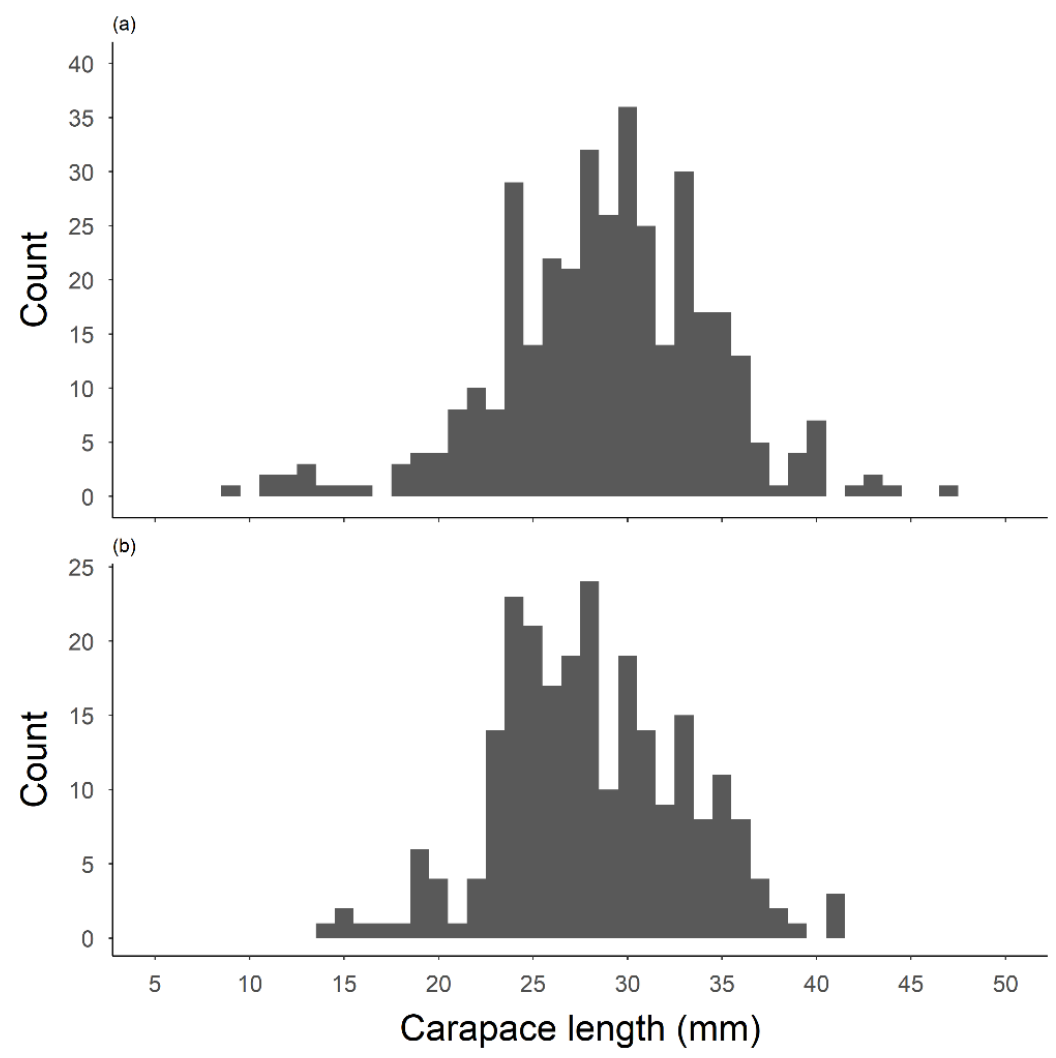

Figure 4. Carapace length $(1.0 \mathrm{~mm})$ of (a) female and (b) male gapped ringed crayfish Faxonius neglectus chaenodactylus sampled in Tumbling Creek Cave during biological surveys. Mean CL of females and males were $28.8 \mathrm{~mm}$ and $28.1 \mathrm{~mm}$, respectively.

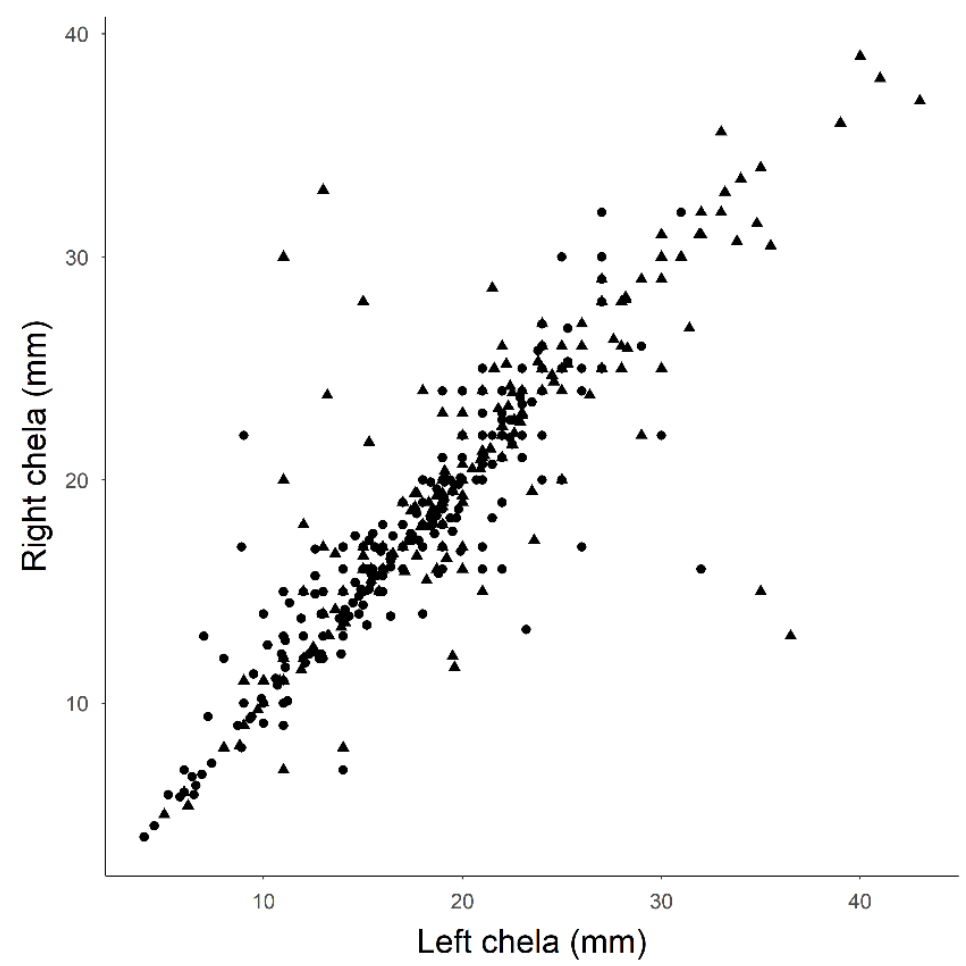

Figure 5. Comparison of the right and left chela length for both males (triangles) and females (circles). Males had significantly larger chelae (20.7 vs. $17.7 \mathrm{~mm}$ ) and a greater difference between right and left chela $\left(Y=0.89 X+2.23 ; R^{2}=0.69\right)$ than did female crayfish $\left(Y=0.92 X+1.18 ; R^{2}=0.81\right)$. 
Reproduction by gapped ringed crayfish appeared to occur regularly within Tumbling Creek Cave. We collected gravid females $(\mathrm{N}=44)$ during many months of the year except January, July, and September. Most gravid females were collected during the spring (February-June, $\mathrm{N}=35$ ) but 1-3 individuals were captured regularly in August, and October through December. Gravid females were recorded every year except 2004, 2007, 2009, 2010, 2013, 2014, and 2017, with the most being recorded in $2015(\mathrm{~N}=13)$. Thus far, we collected 7 gravid females in 2018.

\subsection{Crayfish Removal}

Removal efforts have been effective at reducing the population abundance of gapped ringed crayfish. A total of 4881 crayfish were captured and removed from the cave from June 2011 to September 2018 across 283 removal events. Before removal began, 20 crayfish were typically captured at each sampling event $(\approx 1.7$ per trap). After removal, about 18 crayfish were captured per sampling event $(\approx 0.5$ per trap). Crayfish numbers standardized by trap reflect a general decline over time (Figure 6) though effort also increased over time. Average standardized crayfish catch per year reflected a negative trend over time $\left(Y=-0.10 \mathrm{X}+198.60 ; \mathrm{R}^{2}=0.45\right)$. Of the crayfish removed, 280 were coarsely classified as large ( $>6.4-\mathrm{cm}$ TL), 2077 as medium (3.8-6.4-cm TL), 1042 as small $(1.3-3.7-\mathrm{cm}$ $\mathrm{TL})$, and 302 as very small $(<1.3-\mathrm{cm}$ TL). Each round of removal trapping costs approximately $\$ 200$ USD in labor and supplies.

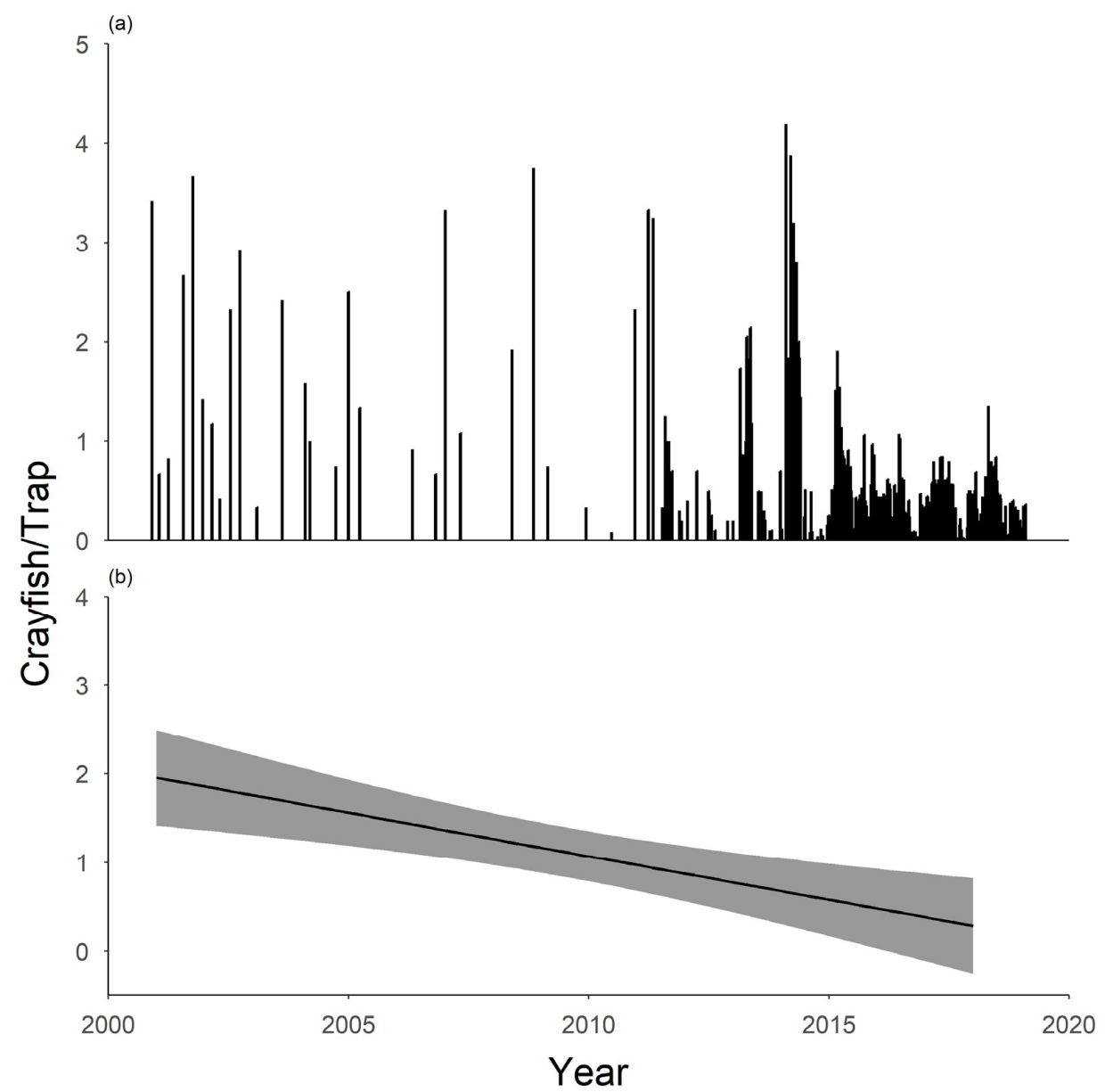

Figure 6. The trend in number of gapped ringed crayfish Faxonius neglectus chaenodactylus captured in Tumbling Creek Cave (17 March 2001-05 September 2018). The number of crayfish capture per trap (a) has greatly been reduced since trapping began and can be best represented as $(\mathbf{b})$ average crayfish per trap, per year, over time $\left(Y=-0.10 X+198.60 ; R^{2}=0.45\right)$. 


\subsection{Age Comparison of Surface and Subterranean Populations}

Cave populations of gapped ringed crayfish lived longer than the populations in the nearby surface stream. The length-frequency histogram we developed reflected four age classes present in the surface population (Table 1; Figure 7). Surface crayfish aged via the gastric mill ranged from $0-4$ years. Age estimates provided using the gastric mill generally agreed with the length-frequency histograms, but as expected, the gastric mills suggest the population lives longer than reflected by the histogram (see discussion). Crayfish collected from the cave ranged from 0-6 years, and there was a greater abundance of the $30-\mathrm{mm}+\mathrm{CL}$ (i.e., older) individuals in the cave population (17 vs. 5).

Table 1. The carapace length (CL) range, mean ( \pm standard deviation), and separation index (SI) of age classes are reported for gapped ringed crayfish Faxonius neglectus chaenodactylus sampled from Big Creek near the confluence of Tumbling Creek. The separation index describes the degree of separation between age classes (i.e., a SI of $<2$ describes a cohort that cannot be distinguished from other cohorts). Data were generated using the Bhattacharya method and compared to age estimates from counting bands on the gastric mills.

\begin{tabular}{cccc}
\hline Age & CL range $(\mathbf{m m})$ & Mean $(\mathbf{m m})$ & SI \\
\hline 0 & $12-23$ & $16.9 \pm 2.7$ & 3.9 \\
1 & $21-26$ & $22.9 \pm 1.2$ & 17.2 \\
2 & $24-31$ & $27.6 \pm 1.5$ & 10.8 \\
3 & $31-36$ & $34.3 \pm 2.1$ & NA \\
\hline
\end{tabular}

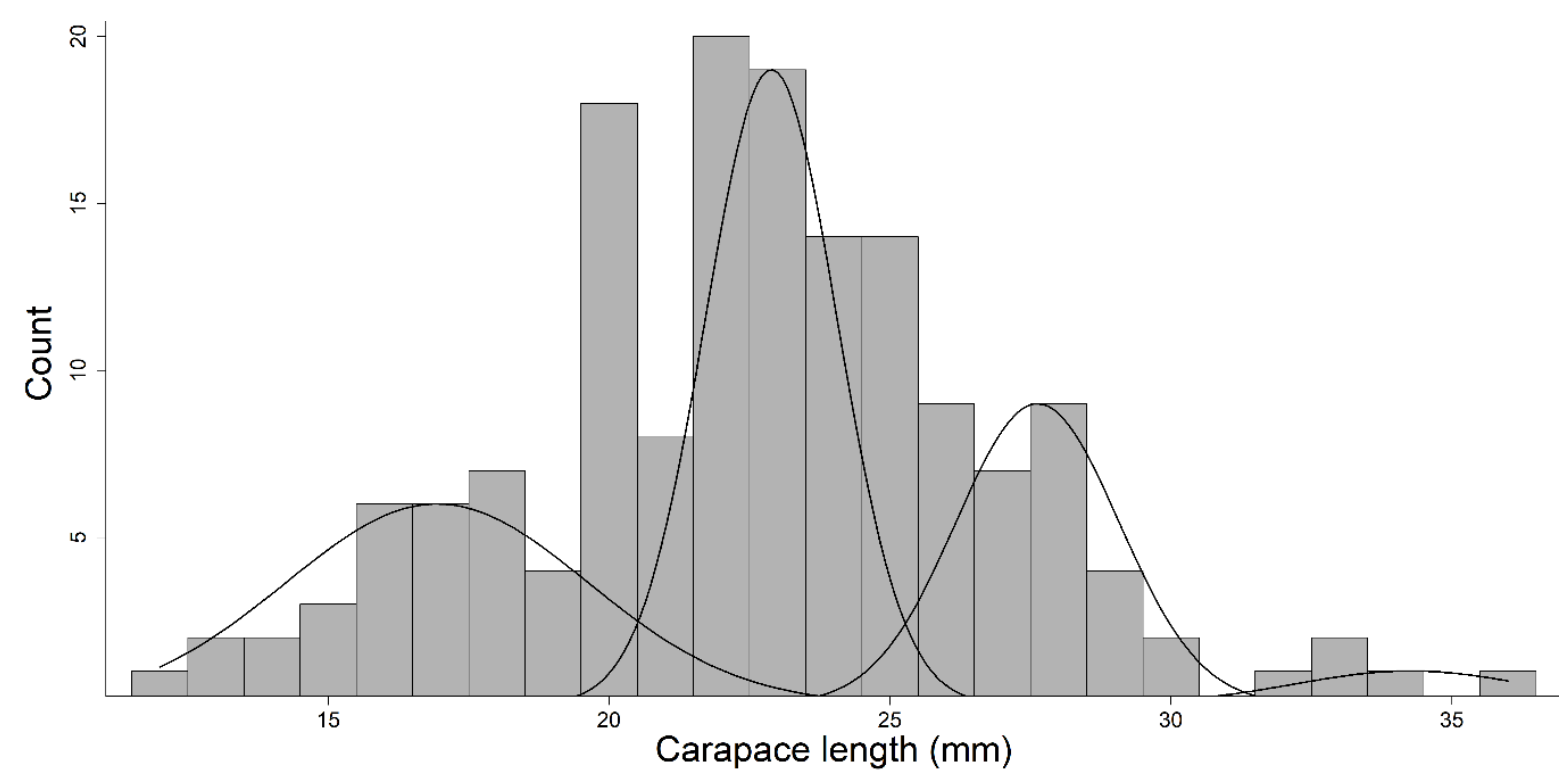

Figure 7. Length-frequency histogram of gapped ringed crayfish Faxonius neglectus chaenodactylus collected from Big Creek near the confluence of Tumbling Creek. Crayfish were collected via seining and hand searching and collection. The black curves represent age classes determined via the Bhattacharya method.

\subsection{Barrier Installations}

Barriers may prove useful in reducing upstream migration by crayfish entering the cave system, but they are costly. The v-notch weir placed to measure discharge in 1968 seemed to have inadvertently reduced upstream migrations by the gapped ring crayfish. Biological surveys removed only 9 crayfish from above the weir. As of 20 February 2015, 1875 crayfish were removed from the cave through removal efforts (i.e., not biological sampling) and only one crayfish was captured upstream of the weir though less sampling effort was also placed in that area. Based on our limited data collected thus far, the barrier installed in spring 2018 reduced crayfish. Since the barrier was completed, only a few 
crayfish have been removed from above the barrier. Total cost of installing the barrier was $\$ 6500$ USD in labor and material.

\section{Discussion}

Our data suggest that gapped ringed crayfish may act as an invasive species in caves such as described for Tumbling Creek Cave. It is unclear what has led the gapped ringed crayfish to invade Tumbling Creek Cave, but current hypotheses suggest rising reservoir levels and perhaps climate change are concerns. High water levels in the nearby Bull Shoals Reservoir inundates the springs that drain to the cave, which may facilitate movement of gapped ringed crayfish into the cave. Climate change is predicted to change the range of many fish species $[34,35]$ and it is possible that the changing climate may have driven gapped ringed crayfish to seek the more stable and cooler thermal refuge of Tumbling Creek Cave. Regardless of why they entered the cave, gapped ringed crayfish are capable of establishing populations relatively high in abundance that warrant substantial financial efforts to reduce. This is especially important in areas where predation risk on federally threated and endangered species may be heightened, as is the case for the endangered Tumbling Creek cavesnail. Future efforts to identify non-native crayfish routes into cave systems via mark-recapture would aide decisions about locations to install barriers. Further, determining the thermal tolerances and habitat needs of native epigean crayfish would be beneficial to predicting possible karst invaders based on these requirements (i.e., will warmer water temperatures of streams and reservoirs push epigean crayfish into caves to seek refuge?).

Gapped ringed crayfish invasions into the cave and subsequent human pressure appear to have caused a shift in their life-history traits. For example, we found that gapped ringed crayfish residing in the cave were often larger, lived longer, and reproduced most months of the years. Despite intensive seining and hand capture of crayfish in the surface stream, we were only able to locate five crayfish that were larger than 30-mm CL. Alternatively, in our most recent removal trapping within the cave, 17 crayfish larger than 30-mm CL were captured. Additionally, the surface crayfish only had a longevity of 4 years, whereas the cave population lived to at least age 6 . Life-history shifts are often noted for species that are introduced to novel environments. For example, Trinidadian guppies Poecilia reticulata that moved from low to high predation streams matured at larger sizes and reproduced more slowly [36]. Cave ecosystems have relatively stable temperatures and fewer predators compared to surface environments [37], which may allow gapped ringed crayfish to live longer and reproduce more often. Although we found gapped ringed crayfish to reproduce during all seasons in the cave, data from surface streams suggest females produce eggs from March through June, with later egg production occurring in spring-fed streams with cooler water temperatures [38]. Human pressure from trapping may have also caused gapped ringed crayfish to increase reproduction [39].

It was not surprising that aging gapped ring crayfish using the gastric mill reflected increased longevity within the population when compared to our length-frequency histograms. Typically, there are fewer larger individuals within a population, thereby increasing the difficulty of discerning older age classes using length-frequency data [28]. Although length-frequency histograms are the most common approach for discerning estimated ages of crayfishes [40], the approach can also be hindered by individuals in a population that grow at different rates [29]. Similar observations of discrepancies between estimated ages of the ringed crayfish (i.e., the other subspecies) using the gastric mill and length-frequency histograms has been noted (e.g., Faxonius neglectus neglectus; [30]).

It is surprising that the population of epigean crayfish seems to be stable deep within Tumbling Creek Cave. Cave biologists usually consider caves to be nutrient-poor habitats with lower biodiversity and lower population levels than occur in surface habitats [41]. The top consumers in cave trophic interactions are usually small salamanders, cavefishes, and/or crayfishes. Surface crayfishes often visit the twilight zone of caves, but often do not do well (i.e., lack of food or inability to reproduce) in the deeper reaches. There are few reports of gravid surface crayfish in caves [42]. A major factor that contributes to the biodiversity of Tumbling Creek Cave is the presence of a maternity colony 
of gray bats. This colony imports nutrients as guano piles that increase the food base in the cave's decomposer-based food web [43-45]. We hypothesize the gapped ringed crayfish has been able to thrive in Tumbling Creek Cave because of this extensive food base.

Intensive manual removal of crayfish from Tumbling Creek Cave has effectively reduced the population (i.e., numbers observed or trapped), but the population persists. Despite increased removal effort throughout the years (i.e., traps placed weekly increased from 10 to 55), the population remains; however, removal activities have substantially reduced the crayfish population in the reaches of the cave stream where the endangered cavesnail is found. Even though invasive populations typically cannot be eliminated, intensive removal can have positive results that meet conservation goals [39]. For example, removal of red swamp crayfish Procambarus clarkii from a stream in California allowed California newt Taricha torosa to reproduce [46] and removal of rusty crayfish Faxonius rusticus has led to the recovery of native macrophytes and fishes in Wisconsin [21].

The addition of barriers within the cave have reduced the upstream movement by gapped ringed crayfish, but may have unintended consequences. Kerby et al. [47] showed that barriers can limit the spread of red swamp crayfish in California. Unfortunately, the addition of barriers in stream ecosystems may alter the flow regime, the temperature, and inhibit movement of organisms in stream ecosystems [48]. In our study, highly mobile stream-dwelling species are not common downstream of where the barrier was placed and it was designed to allow water to flow semi-naturally. We have never captured a cave crayfish or cavefish within the cave, but if they occur within the system, they are seemingly rare and may occupy sections of the cave that are difficult to access. However, future monitoring is advised to ensure barriers do not have unintended consequences on cave-adapted species (e.g., gene flow) or those species that traverse both the subterranean and epigean environments (e.g., cave salamander Eurycea lucifuga; [49]). However, knowledge of the dispersal abilities of native cave organisms might alleviate some of the more obvious concerns for species that traverse the subterranean-epigean environments. Avoiding critical locations where movements are anticipated, such as the twilight zone, might alleviate some concerns; however, consideration of each organism's life history and metapopulation dynamics seems prudent prior to barrier installation in any karst environment.

Our study results can help inform future conservation and management decisions concerning crayfish invasions in caves, especially with the gapped ringed crayfish. We lack basic information on crayfish traits specific to species and populations, an impediment for developing useful management strategies [50]. Trait data, for example, has been used to predict crayfish species that were hypothesized to become invasive or extinct [51]. Further, the trait data reported in this study will help develop a foundation for examining how human pressures or exploitation of new environments might lead to altered trait characteristics (e.g., longevity). Developing databases of trait data would be beneficial to determining how these invasive populations cope with the physicochemical and biological challenges of occupying different environments. Finally, we show that barriers may be an effective strategy for reducing invasive crayfish populations and the cost is comparable to the long-term costs of regular removal efforts.

Author Contributions: Individual author contributions were: conceptualization, D.C.A. and T.A.; methodology, D.C.A. and T.A.; analysis, J.M., S.K.B., and D.C.A.; investigation, all authors; resources, all authors; data curation, David Ashley; writing-J.M., S.B., and D.C.A.; writing-Review and editing, J.M., S.B., and D.C.A.; supervision, T.A., D.C.A., and S.B.; project administration, D.C.A., T.A.; funding acquisition, D.C.A. and T.A.

Funding: This work was funded by the Missouri Department of Conservation (F11AC00484), The Tumbling Creek Cave Foundation (no grant number), and the U.S. Fish and Wildlife Service (Grants 301818G109; 301810G050).

Acknowledgments: This research is a contribution of the Oklahoma Cooperative Fish and Wildlife Research Unit (U.S. Geological Survey, Oklahoma Department of Wildlife Conservation, Oklahoma State University, and Wildlife Management Institute cooperating). We thank David Woods, Paul McKenzie, Tobias Mildenberger, Kimberly Brown, and staff members of the Ozark Underground Laboratory for technical assistance. Any use of trade, firm, or product names is for descriptive purposes only and does not imply endorsement by the U.S. Government. 
Conflicts of Interest: The authors declare no conflict of interest. The funders had no role in the design of the study; in the collection, analyses, or interpretation of data; in the writing of the manuscript, or in the decision to publish the results.

\section{References}

1. Sala, O.E.; Chapin, F.S., III; Armesto, J.J.; Berlow, E.; Bloomfield, J.; Dirzo, R.; Huber-Sanwald, E.; Huenneke, L.F.; Jackson, R.B.; Kinzig, A.; et al. Global biodiversity scenarios for the year 2100. Science 2000, 287, 1770-1774. [CrossRef] [PubMed]

2. Dudgeon, D.; Arthington, A.H.; Gessner, M.O.; Kawabata, Z.; Knowler, D.J.; Lévêque, C.; Naiman, R.J.; Prieur-Richard, A.; Soto, D.; Stiassny, M.L.J.; et al. Freshwater biodiversity: Importance, threats, status and conservation challenges. Biol. Rev. 2006, 81, 163-182. [CrossRef] [PubMed]

3. Taylor, C.A.; Schuster, G.A.; Cooper, J.E.; DiStefano, R.J.; Eversole, A.G.; Hamr, P.; Hobbs, H.H., III; Robison, H.W.; Skelton, C.E.; Thoma, R.F. A reassessment of the conservation status of crayfishes in the United States and Canada after 10+ years of increased awareness. Fisheries 2007, 32, 372-389. [CrossRef]

4. Momot, W.T. Redefining the role of crayfish in aquatic ecosystems. Rev. Fish. Sci. 1995, 3, 33-63. [CrossRef]

5. Carreira, B.M.; Dias, M.P.; Rebelo, R. How consumption and fragmentation of macrophytes by the invasive crayfish Procambarus clarkii shape the macrophyte communities of temporary ponds. Hydrobiologia 2014, 721, 89-98. [CrossRef]

6. Mathers, K.L.; Chadd, R.P.; Dunbar, M.J.; Extence, C.A.; Reeds, J.; Rice, S.P.; Wood, P.J. The long-term effects of invasive signal crayfish (Pacifastacus leniusculus) on instream macroinvertebrate communities. Sci. Total Environ. 2016, 556, 207-218. [CrossRef] [PubMed]

7. Ilhéu, M.; Bernado, J.M.; Fernandes, S. Predation of invasive crayfish on aquatic vertebrates: The effect of Procambarus clarkii on fish assemblages in Mediterranean temporary streams. In Biological Invaders in Inland Waters: Profiles, Distribution, and Threats; Invading Nature-Springer Series in Invasion Ecology; Gherardi, F., Ed.; Springer: Dordrecht, The Netherlands, 2007; Volume 2, pp. 543-558. ISBN 978-1-4020-6028-1.

8. Nunes, A.L.; Richter-Boix, A.; Laurila, A.; Rebelo, R. Do anuran larvae respond behaviourally to chemical cues from an invasive crayfish predator? A community-wide study. Oecologia 2014, 171, 115-127. [CrossRef] [PubMed]

9. Lodge, D.M.; Taylor, C.A.; Holdich, D.M.; Skurdal, J. Nonindigenous crayfishes threaten North American freshwater biodiversity: Lessons from Europe. Fisheries 2000, 25, 7-20. [CrossRef]

10. Mazza, G.; Reboleira, A.S.P.S.; Goncalves, F.; Aquiloni, L.; Inghilesi, A.F.; Spigoli, D.; Stoch, F.; Taiti, S.; Gherardi, F.; Tricarico, E. A new threat to groundwater ecosystems: First occurrences of the invasive crayfish Procambarus clarkii (Girard, 1852) in European caves. J. Caves Karst Stud. 2014, 76, 62-65. [CrossRef]

11. Gibert, J.; Culver, D.C.; Dole-Olivier, M.; Malard, F.; Christman, M.C.; Deharveng, L. Assessing and conserving groundwater biodiversity: Synthesis and perspectives. Freshw. Biol. 2009, 54, 930-941. [CrossRef]

12. Venarsky, M.P.; Huryn, A.D.; Benstead, J.P. Re-examining extreme longevity of the cave crayfish Orconectes australis using new mark-recapture data: A lesson on the limitations of iterative size-at-age models. Freshw. Biol. 2012, 57, 1471-1481. [CrossRef]

13. Notenboom, J.; Plénet, S.; Turquin, M.J. Groundwater contamination and its impact on groundwater animals and ecosystems. In Groundwater Ecology; Gibert, J., Danielopol, D.L., Stanford, J.A., Eds.; Academic Press: Cambridge, MA, USA, 2009; pp. 477-504. ISBN 978-0-0805-0762-0.

14. Morris, B.L.; Lawrence, A.R.L.; Chilton, P.J.C.; Adams, B.; Calow, R.C.; Klinck, B.A. Groundwater and Its Susceptibility to Degradation: A Global Assessment of the Problem and Options for Management; Early Warning and Assessment Report Series, RS. 03-3; United Nations Environment Programme: Nairobi, Kenya, 2003; ISBN 92-807-2297-2.

15. Daniels, R.A.; Murphy, D.C.; Klemens, M.W. Orconectes neglectus is established in the northeast. Northeast. Nat. 2001, 8, 93-100. [CrossRef]

16. Pearl, C.A.; Adams, M.J.; McCreary, B. Habitat and co-occurrence of native and invasive crayfish in the Pacific Northwest, USA. Aquat. Invasions 2013, 8, 171-184. [CrossRef] 
17. Imhoff, E.M.; Moore, M.J.; DiStefano, R.J. Introduced alien ringed crayfish (Orconectes neglectus neglectus [Faxon, 1885]) threaten imperiled coldwater crayfish (Orconectes eupunctus Williams, 1952) in the Eleven Point River drainage, Missouri, USA. Aquat. Invasions 2012, 7, 129-134. [CrossRef]

18. Graening, G.O.; Fenolio, D.B.; Slay, M.E. Cave Life of Oklahoma and Arkansas: Exploration and Conservation of Subterranean Biodiversity; University of Oklahoma Press: Norman, OK, USA, 2011; ISBN 978-0-8061-4424-5.

19. Elliot, W.R. Zoogeography and biodiversity of Missouri caves and karst. J. Caves Karst Stud. 2007, 69, $135-162$.

20. Elliot, W.R. A Guide to Missouri's Cave Life: 70 Cave Species Brought to Light; Missouri Department of Conservation: Jefferson City, MO, USA, 2003. Available online: http:/ / www.mospeleo.org/sites/default/ files / Attachements / A\%20Guide\%20to\%20Missouri\%20Cave\%20Life.pdf (accessed on 26 September 2018).

21. Hein, C.L.; Zanden, M.J.V.; Magnuson, J.J. Intensive trapping and increased fish predation cause massive population decline of an invasive crayfish. Freshw. Biol. 2007, 52, 1134-1146. [CrossRef]

22. Woods, A.J.; Omernik, J.M.; Butler, D.R.; Ford, J.G.; Henley, J.E.; Hoagland, B.W.; Arndt, D.S.; Morgan, B.C. Ecoregions of Oklahoma. U.S. Geological Survey, map scale 1:1,250,000; U.S. Geological Survey: Reston, VA, USA, 2005. Available online: https:/ / www.epa.gov/eco-research/ecoregion-download-files-state-region-6 (accessed on 26 September 2018).

23. Dillman, C.B. Molecular Systematics, Biogeography, and Phylogeography of North American Freshwater Crayfishes (Decapoda: Cambaridae): With Emphasis on the Genera Cambarus and Orconectes. Ph.D. Thesis, Saint Louis University, Saint Louis, MO, USA, 2008.

24. Fish and Wildlife Service. Endangered and Threatened Wildlife and Plants; Listing the Tumbling Creek Cavesnail as Endangered; Fish and Wildlife Service: Columbia, SC, USA, 2001. Available online: www.gpo.gov/fdsys/search/ citation.result.FR.action?federalRegister.volume=2001\&federalRegister. page $=66803 \&$ publication $=$ FR (accessed on 26 September 2018).

25. Missouri Department of Conservation. Missouri Species and Communities of Conservation Concern Checklist; Missouri Department of Conservation: Jefferson City, MO, USA, 2018. Available online: https://nature.mdc. mo.gov/sites/default/files/downloads/2018_SOCC.pdf (accessed on 26 September 2018).

26. Phillips, J.G.; Fenolio, D.B.; Emel, S.L.; Bonett, R.M. Hydrologic and geologic history of the Ozark Plateau drive phylogenomic patterns in a cave-obligate salamander. J. Biogeogr. 2017, 440, 2463-2474. [CrossRef]

27. Jurcak, A.M.; Lahman, S.E.; Wofford, S.J.; Moore, P.A. Behavior of Crayfish. In Biology and Ecology of Crayfish; Longshaw, M., Stebbing, B., Eds.; CRC Press: Boca Raton, FL, USA, 2016; pp. 117-131. ISBN 978-1-4987-6732-3.

28. France, R.; Holmes, J.; Lynch, A. Use of size-frequency data to estimate the age composition of crayfish populations. Can. J. Fish. Aquat. Sci. 1991, 48, 2324-2332. [CrossRef]

29. Kilada, R.; Sainte-Marie, B.; Rochette, R.; Davis, N.; Vanier, C.; Campana, S. Direct determination of age in shrimps, crabs, and lobsters. Can. J. Fish. Aquat. Sci. 2012, 69, 1728-1733. [CrossRef]

30. Mouser, J.M.; Glover, J.; Brewer, S.K. Comparing age estimates of freshwater crayfish using gastric mill bands and length-frequency histograms. Unpublished: Manuscript in preparation.

31. Bhattacharya, C.G. A simple method of resolution of a distribution into Gaussian components. Biometrics 1967, 23, 115-135. [CrossRef] [PubMed]

32. Mildenberger, T.K.; Taylor, M.H.; Wolff, M. TropFishR: An R package for fisheries analysis with length-frequency data. Methods Ecol. Evol. 2017, 8, 1520-1527. [CrossRef]

33. Gayanilo, F.C.; Sparre, P.; Pauly, D. FAO-ICLARM Stock Assessment Tools II: User's Guide; Food and Agriculture Organization: Rome, Italy, 2005; ISBN 92-5-105300-6.

34. Chu, C.; Mandrak, N.E.; Minns, C.K. Potential impacts of climate change on the distributions of several common and rare freshwater fishes in Canada. Divers. Distrib. 2005, 11, 299-310. [CrossRef]

35. Rahel, F.J.; Olden, J.D. Assessing the effects of climate change on aquatic invasive species. Conserv. Biol. 2008, 22, 521-533. [CrossRef] [PubMed]

36. Reznick, D.N.; Bryga, H. Life-history evolution in guppies (Poecilia reticulata): 1. Phenotypic and genetic changes in an introduction experiment. Evolution 1987, 41, 1370-1385. [CrossRef] [PubMed]

37. Huppop, K. Adaptation to low food. In Encyclopedia of Caves, 3rd ed.; White, W.B., Culver, D.C., Eds.; Academic Press: Waltham, MA, USA, 2012; pp. 99-102. ISBN 978-0-123-83832-2.

38. Pflieger, W.L. The Crayfishes of Missouri; Missouri Department of Conservation: Jefferson City, MO, USA, 1996; ISBN 1-887247-05-X. 
39. Stebbing, P.; Longshaw, M.; Scott, A. Review of methods for the management of nonindigenous crayfish, with particular reference to Great Britain. Ethol. Ecol. Evol. 2014, 26, 204-231. [CrossRef]

40. Reynolds, J.D. Growth and reproduction. In Biology of Freshwater Crayfish; Holdich, D.M., Ed.; Blackwell Science: Oxford, UK, 2002; pp. 152-191. ISBN 978-0-632-05431-2.

41. Ashley, D.C. Missouri cave biology. In Hitchhiker's Guide to Missouri Caving. 2015 NSS Convention Guidebook; Slais, D., Ed.; World Press: Fenton, MO, USA, 2015; pp. 67-70.

42. Fenolio, D.; Niemiller, M.L.; Soares, D.; Slay, M.; Harris, A.; Harris, N. Subterranean reproduction of the Ringed Crayfish, Orconectes neglectus Faxon 1885 (Astacoidea: Cambaridae) within an Ozark Highlands cave in Oklahoma, USA. Speleobiol. Notes 2013, 5, 43-46. [CrossRef]

43. Fenolio, D.B.; Graening, G.O.; Collier, B.A.; Stout, J.F. Coprophagy in a cave-adapted salamander; the importance of bat guano examined through nutritional and stable isotope analyses. Proc. R. Soc. B 2006, 273, 439-443. [CrossRef]

44. Humphreys, W.F. Experimental re-establishment of pulse-driven populations in a terrestrial troglobite community. J. Anim. Ecol. 1991, 60, 609-623. [CrossRef]

45. Poulson, T.L. Food sources. In Encyclopedia of Caves, 3rd ed.; White, W.B., Culver, D.C., Eds.; Academic Press: Waltham, MA, USA, 2012; pp. 255-264. ISBN 978-0-123-83832-2.

46. Kats, L.B.; Bucciarelli, G.; Vandergon, T.L.; Honeycutt, R.L.; Mattiasen, E.; Sanders, A.; Riley, S.P.D.; Kerby, J.L.; Fisher, R.N. Effects of natural flooding and manual trapping on the facilitation of invasive crayfish-native amphibian coexistence in a semi-arid perennial stream. J. Arid Environ. 2013, 98, 109-112. [CrossRef]

47. Kerby, J.L.; Riley, S.P.D.; Kats, LB.; Wilson, P. Barriers and flow as limiting factors in the spread of an invasive crayfish (Procambarus clarkii) in southern California streams. Biol. Conserv. 2005, 126, 402-409. [CrossRef]

48. Ellis, L.E.; Jones, N.E. Longitudinal trends in regulated rivers: A review and synthesis within the context of the serial discontinuity concept. Environ. Rev. 2013, 21, 136-148. [CrossRef]

49. Wilson, P.N. Movement patterns of the cave salamander (Eurycea lucifuga) in Sauerkraut Cave, Kentucky. Honors Thesis, University of Louisville, Louisville, KY, USA, 2016. Available online: http:// doi.org/10. 18297/honors/121 (accessed on 2 December 2018).

50. Moore, M.J.; DiStefano, R.J.; Larson, E.R. An assessment of life-history studies for USA and Canadian crayfishes: Identifying biases and knowledge gaps to improve conservation and management. Freshw. Sci. 2013, 32, 1276-1287. [CrossRef]

51. Larson, E.R.; Olden, J.D. Latent extinction and invasion risk of crayfishes in the Southeastern United States. Conserv. Biol. 2010, 24, 1099-1110. [CrossRef] [PubMed] 